\title{
Introduction
}

\section{Ross Williams*}

*Melbourne Institute, University of Melbourne, Victoria 3010, Australia; email <rossaw@unimelb.edu.au>.

In 2016 the federal government requested the Productivity Commission to undertake an inquiry into Australia's productivity performance and provide recommendations on productivity-enhancing reform. The request arose in part because of concerns about the fall off in measured productivity in recent years. The terms of reference (Productivity Commission 2017, p.3) explain the motivation further:

It is particularly important at present that policy settings facilitate structural change and productive investment in the economy to support its transition from the resources investment boom, and promote its efficiency and competitiveness given population ageing and evolving global economy.

This is the author manuscript accepted for publication and has undergone full peer review but has not been through the copyediting, typesetting, pagination and proofreading process, which may lead to differences between this version and the Version of Record. Please cite this article as doi:10.1111/aere.12276 
The subsequent Report, entitled Shifting the Dial: 5 Year Productivity Review, was published in October 2017. It is envisaged that this will be the first of regular five-year reviews. The main Report is supplemented by 16 supporting papers of more detailed analysis.

The Report critically examines current practices and makes recommendations in five general areas: health, education/training, cities, market efficiencies and government. The first three areas were chosen because reform is longer term and more fundamental. They are also sectors that involve both public and private providers. In this Forum selected aspects of the Report are examined: health, education/training and taxation arrangements. A final article addresses the issue of productivity measurement.

The first sectoral chapter of the Commission's Report is entitled 'Healthier Australians'. The recommendations are set out and carefully evaluated by Anthony Scott in the first article in this Forum. He concludes, along with the Commission, that the issues boil down to 'the basis of any well-functioning market: information and system design'. One of the most politically difficult recommendations is to change the pharmacy model to one which anticipates automatic dispensing and moves away from community pharmacy. Pharmacists would then play a collaborative clinical role with other primary health professionals. The Commission recognises that this change has significant implications for tertiary institutions.

Chapter 3 of the Commission's Report sensibly links education with work skills and the labour market. International benchmarking is now a favoured way of evaluating education systems. Concern about school performance has in part been driven by the scores obtained in the OECD Programme for International Student Assessment (PISA). Mean scores for Australian students are in the middle range for OECD and East Asian countries and have been falling in absolute levels. In the 2015 results, Australia ranked 16th for reading and 25 th for mathematics. These ranks for generic skills carry over to those with tertiary education. In the OECD Programme for Assessment of Adult Competencies (PIACC), Australians aged between 20 and 25 with tertiary education are ranked 14th for literary skills and 21st for numeracy out of 31 countries. ${ }^{1}$ Concurrent with average performance in generic skills has been the ever-present plea from employers about the need for better disciplinespecific skills.

In her Forum article reviewing Chapter 3, Gigi Foster concludes that 'the Productivity Commission's review of Australia's education system is found to be overly narrow, although several of its policy recommendations are sound'. The latter include building the capacity for data-sharing, facilitating better decision making by students and employers through improvements in information, and linking Commonwealth Supported Places (CSP) payments to universities' actual teaching costs. Foster notes, however, that the Report underplays the societal benefits that accrue from education such as lower crime and the creativity needed for innovation. Also, there is a 'comparatively perfunctory consideration of non-university tertiary education', which 'under-weights the potential productivity gains to be had by further supporting the TAFE and vocational education sector'.

In his Forum article, John Quiggin argues that the Productivity Commission's recommendations in health and education do not go far enough. In his view, more radical measures are needed to raise the rate of growth of output per person by a substantial amount. In a similar vein to Foster, Quiggin regrets what he sees as the Report's failure to seriously consider further expanding post-school education.

Chapter 4 of the Report is entitled 'Better Functioning Towns and Cities'. Recommendations include better economic evaluation of major infrastructure proposals, a greater use of user-pays principles

This article is protected by copyright. All rights reserved. 
for road use and an improvement in consultation and planning processes. The final recommendation is to move from stamp duties on residential and commercial properties to a broad-based land tax on the unimproved value of land. This recommendation overlaps with the subject matter of Chapter 6 that covers government performance, including public finances. Here, the Productivity Commission's recommendations include a joint Commonwealth-State agreement to a formal joint reform agenda to be monitored by an independent body. In this and other areas the Commission argues that local government should also be involved.

In his evaluation of Chapter 6, John Freebairn notes that 'rather than another review of taxation and reform options' the Commission 'focuses on changes in government procedures to facilitate turning available reform ideas into actual taxation reforms'. Freebairn observes that in the Report there is 'no priority ranking of the many reform options, nor details of specific recommended reform packages'. Freebairn provides a taxonomy of current taxes levelled by the three levels of government in Australia, with their relative importance and potential reforms. He enunciates his overall view that taxation reforms to support higher national productivity and living standards should combine comprehensive bases and lower rates and a shifting of the tax mix to taxes with low response elasticities.

The ultimate aim of economic reform is to improve standards of living. This encompasses increases in measured income per head, minimum income levels and the quality of life as reflected by indicators such as average length of life and a safe and clean environment. An improvement in efficiency in the sense of the same output from fewer inputs is unambiguously desirable. The Productivity Commission's Report is fundamentally concerned with finding better ways of doing things in selected areas. Sector-specific indicators can provide evidence of subsequent success or failure. It is when economists try and measure overall success by a single measure that controversies arise.

The introductory chapter of the Productivity Commission's Report contains a section that reviews aggregate productivity movements from 1890 and in more detail over recent decades. The measurement of productivity presents both theoretical and empirical problems. Conceptually, how should labour and capital inputs be measured? How do we deal adequately with the non-market services sector? Multifactor productivity (MFP) is designed to measure the overall efficiency with which labour and capital inputs are used together in the production process. It principle it measures that part of GDP growth that cannot be explained by changes in labour and capital inputs. The Commission notes that measured MFP has been essentially static since 2002. On the other hand, labour productivity in the market sector, measured as real output per hour, has stayed mainly in the band between 2 and 2.5 per cent per year over several decades.

John Quiggin argues in his Forum article that the reason MFP appears static is because progress in information and technology, and in labour quality through education, is embodied in the input measures. In his view 'productivity growth arises almost entirely from the combination of bettereducated workers and better and cheaper technology'. While Quiggin contrasts this with 'microeconomic reform' it leaves open the question of how to better educate workers and the structures needed to encourage the introduction and use of new technology. The Productivity Commission's Report provides some answers to these questions. 
Reference

Productivity Commission 2017, Shifting the Dial: 5 Year Productivity Review, Report 84, Productivity Commission, Canberra.

\footnotetext{
${ }^{1}$ The most convenient way to access this data is the US National Centre for Education Statistics https://nces.ed.gov/surveys/international/ide/
} 


\section{University Library}

\section{- M M I N E R VA A gateway to Melbourne's research publications}

Minerva Access is the Institutional Repository of The University of Melbourne

Author/s:

Williams, $\mathrm{R}$

Title:

Introduction

Date:

2018-06-01

Citation:

Williams, R. (2018). Introduction. AUSTRALIAN ECONOMIC REVIEW, 51 (2), pp.244-246. https://doi.org/10.1111/1467-8462.12276.

Persistent Link:

http://hdl.handle.net/11343/284975 